OPEN ACCESS

Edited by:

Chao Deng

University of Wollongong, Australia

Reviewed by:

Ignacio Camacho-Arroyo, National Autonomous University of Mexico, Mexico Abhiram Sahu,

University of Pittsburgh, United States Jingxia Gao,

University of Utah, United States

${ }^{*}$ Correspondence: Csaba Vastagh vastagh.csaba@koki.mta.hu

Received: 08 February 2017 Accepted: 15 June 2017

Published: 04 July 2017

Citation:

Vastagh $C$ and Liposits Z (2017) Impact of Proestrus on Gene Expression in the Medial Preoptic Area of Mice.

Front. Cell. Neurosci. 11:183. doi: 10.3389/fncel.2017.00183

\section{Impact of Proestrus on Gene Expression in the Medial Preoptic Area of Mice}

\author{
Csaba Vastagh ${ }^{1 *}$ and Zsolt Liposits ${ }^{1,2}$ \\ ${ }^{1}$ Laboratory of Endocrine Neurobiology, Institute of Experimental Medicine, Hungarian Academy of Sciences, Budapest, \\ Hungary, ${ }^{2}$ Department of Neuroscience, Faculty of Information Technology and Bionics, Pázmány Péter Catholic University, \\ Budapest, Hungary
}

The antero-ventral periventricular zone (AVPV) and medial preoptic area (MPOA) have been recognized as gonadal hormone receptive regions of the rodent brain that-via wiring to gonadotropin-releasing hormone $(\mathrm{GnRH})$ neurons - contribute to orchestration of the preovulatory $\mathrm{GnRH}$ surge. We hypothesized that neural genes regulating the induction of $\mathrm{GnRH}$ surge show altered expression in proestrus. Therefore, we compared the expression of 48 genes obtained from intact proestrous and metestrous mice, respectively, by quantitative real-time PCR (qPCR) method. Differential expression of 24 genes reached significance $(p<0.05)$. Genes upregulated in proestrus encoded neuropeptides (kisspeptin (KP), galanin (GAL), neurotensin (NT), cholecystokinin (CCK)), hormone receptors (growth hormone secretagogue receptor, $\mu$-opioid receptor), gonadal steroid receptors (estrogen receptor alpha $(E R \alpha)$, progesterone receptor $(\mathrm{PR})$, androgen receptor $(\mathrm{AR})$ ), solute carrier family proteins (vesicular glutamate transporter 2, vesicular monoamine transporter 2), proteins of transmitter synthesis (tyrosine hydroxylase $(\mathrm{TH})$ ) and transmitter receptor subunit (AMPA4), and other proteins (uncoupling protein 2, nuclear receptor related 1 protein). Proestrus evoked a marked downregulation of genes coding for adenosine A2a receptor, vesicular gamma-aminobutyric acid (GABA) transporter, 4-aminobutyrate aminotransferase, tachykinin precursor 1 , NT receptor 3 , arginine vasopressin receptor $1 \mathrm{~A}$, cannabinoid receptor 1 , ephrin receptor $A 3$ and aldehyde dehydrogenase 1 family, member $L 1$. Immunocytochemistry was used to visualize the proteins encoded by Kiss1, Gal, Cck and Th genes in neuronal subsets of the AVPV/MPOA of the proestrous mice. The results indicate that gene expression of the AVPV/MPOA is significantly modified at late proestrus including genes that code for neuropeptides, gonadal steroid hormone receptors and synaptic vesicle transporters. These events support cellular and neuronal network requirements of the positive estradiol feedback action and contribute to preparation of the $\mathrm{GnRH}$ neuron system for the pre-ovulatory surge release.

Keywords: AVPV, MPOA, mouse, proestrus, metestrus, gene expression, PCR, immunocytochemistry

\section{INTRODUCTION}

The antero-ventral periventricular zone (AVPV) and medial preoptic area (MPOA) referred as AVPV/MPOA, are conspicuous constituents of the rostro-ventral hypothalamus of the rodent brain. This region has a pivotal role in central regulation of reproduction (Barr and Barraclough, 1978; Petersen et al., 1989) and control of paternal behavior 
(Lee and Brown, 2002; Paredes, 2003; Hull and Dominguez, 2007; Tsuneoka et al., 2013; Akther et al., 2014) and social reward (McHenry et al., 2017). It shows the signs of sexual dimorphism by displaying a considerably larger volume and rostro-caudal extent in females than males (Davis et al., 1996). The area has been identified as a main target of gonadal hormone actions. Accordingly, functional estrogen receptor alpha $(\mathrm{ER} \alpha)$ and beta (ER $\beta$; Ehret and Buckenmaier, 1994; Merchenthaler et al., 2004; Bodo et al., 2006; Sano et al., 2013; Zuloaga et al., 2014; Nakata et al., 2016), progesterone receptor (PR; Simerly et al., 1996; Kudwa et al., 2004) and androgen receptor (AR; Simerly et al., 1990) have been described in the region. Its significance in reproduction was reinforced by the pioneer finding that medial preoptic micro-implants of the non-steroidal antiestrogen, Keoxifene blocked the afternoon luteinizing hormone (LH) surge (Petersen et al., 1989). The chemical phenotyping of the area revealed the production of a wide scale of neuropeptides and the synthesis of certain neurotransmitters. Subsets of neurons produce kisspeptin (KP; Smith et al., 2005; Clarkson and Herbison, 2006; Ducret et al., 2010; Overgaard et al., 2013; Kumar et al., 2015; Skrapits et al., 2015; Yip et al., 2015; Yeo et al., 2016), galanin (GAL; Porteous et al., 2011; Wu et al., 2014), cholecystokinin (CCK; Simerly and Swanson, 1987), substance-P (SP; Simerly and Swanson, 1987; Okamura et al., 1994), met-enkephalin (ENK; Simerly and Swanson, 1987; Porteous et al., 2011) and neurotensin (NT; Simerly and Swanson, 1987; Dungan Lemko et al., 2010) representing the peptidergic profile. Synthesis of gamma-aminobutyric acid (GABA; Cravo et al., 2011; Liu and Herbison, 2011; Liu et al., 2011; Cheong et al., 2015), glutamate (Cravo et al., 2011; Liu et al., 2011; Cheong et al., 2015) and dopamine (DA; Simerly and Swanson, 1987; Simerly et al., 1997; Clarkson and Herbison, 2011) in the area proves its capability of networking via neurotransmitter signaling. Neurons with dual phenotype have also been identified in the region (Ottem et al., 2004; Clarkson and Herbison, 2011; Skrapits et al., 2015). Tract tracing studies explored the neuronal projections of the AVPV/MPOA to various loci of the central nervous system indicating its involvement in the control of various neuronal networks (Simerly and Swanson, 1988; Gu and Simerly, 1997; Simerly, 1998).

Regarding its role in the central regulation of reproduction, elucidation of wiring of AVPV/MPOA neurons with gonadotropin-releasing hormone (GnRH) neurons, identification of putative regulatory neurotransmitters and neuropeptides in the established connections and clarification of their regulatory influence upon GnRH network-related functions are indispensable. In mice, the expression of the trans-neuronal genetic tracer, barely lectin (BL) in GnRH neurons allowed the identification of their afferent neuronal systems including projections from the AVPV and MPOA (Boehm et al., 2005). The use of genetic trans-synaptic tracing strategy has also proved that KP afferents of AVPV origin innervate $\mathrm{GnRH}$ neurons, the connection is estrogen sensitive and utilizes DA as co-modulator (Kumar et al., 2015). Subsets of KP neurons in the rostral periventricular regions of the third ventricle (RP3V) co-synthesize GAL and ENK (Porteous et al., 2011). CCK and NT do not seem to act as co-modulators in KP neurons (Porteous et al., 2011). Signaling to GnRH neurons by KP (Han et al., 2005; Clarkson et al., 2008; Kalló et al., 2012), GAL (Kalló et al., 2012), CCK (Giacobini and Wray, 2007), NT (Dungan Lemko et al., 2010) and ENK (Porteous et al., 2011) has also been revealed in rodents. Regarding the neurotransmitter signaling, glutamate- and GABA-ergic inputs to $\mathrm{GnRH}$ cells arising from the AVPV/MPOA have been shown (Cravo et al., 2011) and their impact on GnRH neuron physiology confirmed by electrophysiology (Han et al., 2002; Iremonger et al., 2010; Moenter, 2010; Liu and Herbison, 2011). Likewise, the modulation of GnRH neuron by DA (Liu and Herbison, 2013) has also been established.

The participation of estradiol (E2)-receptive neuron populations of the AVPV/MPOA in mediation and execution of the positive E2 feedback effect has been confirmed (Wintermantel et al., 2006; Christian et al., 2008; Moenter et al., 2009; Dubois et al., 2015). Evidences indicate that circulating E2 activates ER-alpha expressing KP neurons in the MPOA in proestrus (Smith et al., 2006b; Adachi et al., 2007; Clarkson et al., 2008; Clarkson and Herbison, 2009) by modulating ionic currents of these neurons in an estrous cycle dependent manner (Piet et al., 2013).

These observations undoubtedly indicate that the AVPV/MPOA has a substantial contribution to regulation of the GnRH system by relaying the hormonal message of the positive E2 feedback during proestrus. Accordingly, it is conceivable to assume that $\mathrm{E} 2$ modifies the transcriptome of the $\mathrm{RP} 3 \mathrm{~V}$ area preceding the preovulatory GnRH surge. The present study was aimed to monitor proestrus-regulated changes in the transcriptome of the AVPV/MPOA in gonadally intact, cycling female mice obtained from proestrus and metestrus stages of the ovarian cycle, respectively.

\section{MATERIALS AND METHODS}

\section{Ethics Statement}

All experiments were performed with permissions from the Animal Welfare Committee of the Institute of Experimental Medicine Hungarian Academy of Sciences (Permission Number: A5769-01) and in accordance with legal requirements of the European Community (Directive 2010/63/EU). All animal experimentation described was conducted in accordance with accepted standards of humane animal care and all efforts were made to minimize suffering.

\section{Animals}

Adult, gonadally intact C57BL/6J female mice $(n=20)$ were used from local colonies bred at the Medical Gene Technology Unit of the Institute of Experimental Medicine (IEM). They were housed in light (12:12 light-dark cycle, lights on at 06:00 h) - and temperature $\left(22 \pm 2^{\circ} \mathrm{C}\right)$ controlled environment, with free access to standard food and tap water. The estrous cycle was monitored daily between 9 a.m. and 10 a.m. by microscopic evaluation of vaginal cytology (Nelson et al., 1982; Byers et al., 2012; Cora et al., 2015). Proestrous and metestrous female mice with at least two consecutive, regular 
estrous cycles were used. To avoid the circadian effect, animals were sacrificed between 16:00 $\mathrm{h}$ and 18:00 $\mathrm{h}$. We have recently described the biomarkers of these animals reporting that late-proestrous mice are characterized by predominantly nucleated epithelial cells in the vaginal smear, increased serum luteinizing $(\mathrm{LH})$ hormone level $(>5 \mathrm{mg} / \mathrm{L})$, enlarged uterine weight $(>0.15 \mathrm{~g})$ and higher burst activity and firing frequency of GnRH neurons (Farkas et al., 2013; Vastagh et al., 2016) in comparison with metestrous animals. These observations are in good agreement with other reports characterizing the bio-profile of intact proestrous mice (Murr et al., 1973; Czieselsky et al., 2016; Silveira et al., 2017). The uterine wet weight correlates with serum $\mathrm{LH}$ level, therefore, it is considered as a reliable marker of the late proestrous mice developing the pre-ovulatory GnRH surge (Vastagh et al., 2016; Silveira et al., 2017) Accordingly, the uterine weights clearly differentiated between the proestrous and metestrous experimental groups displaying $0.155 \pm 0.013 \mathrm{~g}$ and $0.076 \pm 0.008 \mathrm{~g}$ values, respectively.

\section{Dissection of the AVPV/MPOA Blocks from Mouse Hypothalami}

Proestrous $(n=6)$ and metestrous $(n=6)$ mice were deeply anesthetized, decapitated and then brains were rapidly removed and placed into a pre-chilled brain matrix. A $1 \mathrm{~mm}$-thick coronal slice-extending between Bregma $+0.9 \mathrm{~mm}$ and Bregma $-0.1 \mathrm{~mm}$ as antero-posterior coordinates-was cut from each brain. The bilateral AVPV/MPOA blocks were dissected in a triangle-shape as shown in Figure 3. Tissue blocks were collected individually from the brains and placed immediately in RNAlater (Thermo Fisher Scientific, Waltham, MA, USA) and stored at $-80^{\circ} \mathrm{C}$ until further use.

\section{RNA Isolation, Reverse Transcription and Pre-Amplification}

Dissected tissue blocks containing the AVPV/MPOA were shredded in RLT buffer (Qiagen, Hilden, Germany) supplemented with $1 \%$ beta-mercaptoethanol. Total RNA was isolated from each individual AVPV tissue sample using RNeasy Micro kit (Qiagen, Hilden, Germany) according to manufacturer's protocol. Genomic DNA was eliminated by treatment with $1 \mathrm{U}$ of RNase-free DNase-I (Thermo Fisher Scientific). Total RNA was eluted with $14 \mu \mathrm{l}$ of ribonuclease-free water. For integrity analysis, RNA was measured using RNA Pico Chip on the 2100 Bioanalyzer (Agilent, Santa Clara, CA, USA). Twenty-five nanograms column-purified RNA were reverse transcribed per samples using SuperScript VILO cDNA synthesis kit (Thermo Fisher Scientific). The resultant cDNA product was pre-amplified with TaqMan PreAmp Master Mix Kit (Thermo Fisher Scientific) according to the manufacturer's protocol.

\section{Quantitative Real-Time PCR Studies}

For quantitative real-time PCR (qPCR) investigations of the AVPV/MPOA samples (proestrous females $n=6$, metestrous females $n=6$ ) pre-amplified cDNA diluted in $0.1 \times \mathrm{TE}$ buffer was used as template for qPCR. Inventoried TaqMan assays (Thermo Fisher Scientific) were used in the qPCR investigation. Each assay consisted of a FAM dye-labeled TaqMan MGB probe and two PCR primers. Thermal cycling conditions of the $\mathrm{qPCR}$ were as follows: $2 \mathrm{~min}$ at $50^{\circ} \mathrm{C}$ and $10 \mathrm{~min}$ at $95^{\circ} \mathrm{C}$, followed by 40 cycles of $15 \mathrm{~s}$ at $95^{\circ} \mathrm{C}$ and $1 \mathrm{~min}$ at $60^{\circ} \mathrm{C}$ using ViiA 7 real-time PCR platform (Thermo Fisher Scientific). Using the geometric mean of cycle threshold (Ct) values of the reference genes (Gapdh and Hprt), the relative gene expression (RQ) was calculated by the $2^{-\Delta \Delta \mathrm{Ct}}$ method (Livak and Schmittgen, $2001)$ where $\Delta \Delta \mathrm{Ct}=\left(\mathrm{Ct}_{\text {target }}-\mathrm{Ct}_{\text {reference }}\right)_{\text {proestrus }}-\left(\mathrm{Ct}_{\text {target }}\right.$ $\left.-\mathrm{Ct}_{\text {reference }}\right)_{\text {metestrus }}$.

\section{Statistical Analysis}

Delta $C t$ values $\left(\Delta \mathrm{Ct} ; \mathrm{Ct}_{\text {target }}-\mathrm{Ct}_{\text {reference }}\right)$ for proestrus and metestrus groups were subjected to two-tailed Student's $t$-test to estimate $\Delta \Delta \mathrm{Ct}$ in comparison of gene expression. RQs were expressed as mean \pm SEM, with number of animals $n=4$ per groups. Differences were considered as significant when $p<0.05$.

\section{Immunocytochemistry}

Adult female mice $(n=8)$ were deeply anesthetized and perfused transcardially with $4 \%$ paraformaldehyde in PBS $(\mathrm{pH}=7.4)$ in their proestrus phase between 16:00 $\mathrm{h}$ and 18:00 h. Brains were removed from the skulls and post-fixed for $1 \mathrm{~h}$ at RT, then equilibrated in $30 \%$ sucrose-PBS. Thirty micrometer thick sections were cut in the coronal plane using a freezing microtome (SM2000R, Leica Biosystems, Nussloch, Germany). The sections were washed several times in PBS, then permeabilized with $0.5 \%$ Triton-X100 and blocked in $2 \%$ heat-inactivated normal horse serum (NHS). Primary antisera were diluted in NHS and incubated with the sections for $72 \mathrm{~h}$ at $4^{\circ} \mathrm{C}$. The following antisera were used: anti-KP (\#AC024, 1:5000, from A. Caraty, INRA, Nouzilly, France), anti-galanin (\# IS-42; 1:2000, Interchim Cat\# AP101500, RRID: AB_2314518), anti-CCK-8 (\# IS-15/8 RRID: AB_2314186, 1:1000, from P. Ciofi, National Institute of Health and Medical Research, Bordeaux, France) and anti-tyrosine hydroxylase (TH) (\#TYH, 1:1000; Aves Labs Inc., Tigard, OR, USA). The characterization and specificity of the primary antibodies have been published elsewhere (Ciofi and Tramu, 1990; Porteous et al., 2011), the pre-absorption of the antibodies or their omission from the staining resulted in immunonegative sections. Cy3-conjugated secondary antibodies (Jackson Immunoresearch Europe Ltd, Suffolk, UK) were diluted in PBS containing 2\% NHS (1:500) and applied on the sections for $4 \mathrm{~h}$ at RT. The sections were washed several times in PBS, then were mounted on glass slides and coverslipped in Mowiol (Sigma-Aldrich, St. Louis, MO, USA). Slides were investigated using a Zeiss Axioskop-2 (Carl-Zeiss Microscopy, Jena, Germany) microscope under ultraviolet light using filter set for Cy3 dye (excitation BP 545/25, emission BP 605/70), then sections were photographed with an AxioCam HRc digital camera controlled by AxioVision 4.6 software (CarlZeiss). 
TABLE 1 | PCR analysis of genes regulated differentially in proestrus in the antero-ventral periventricular/medial preoptic area of the mouse.

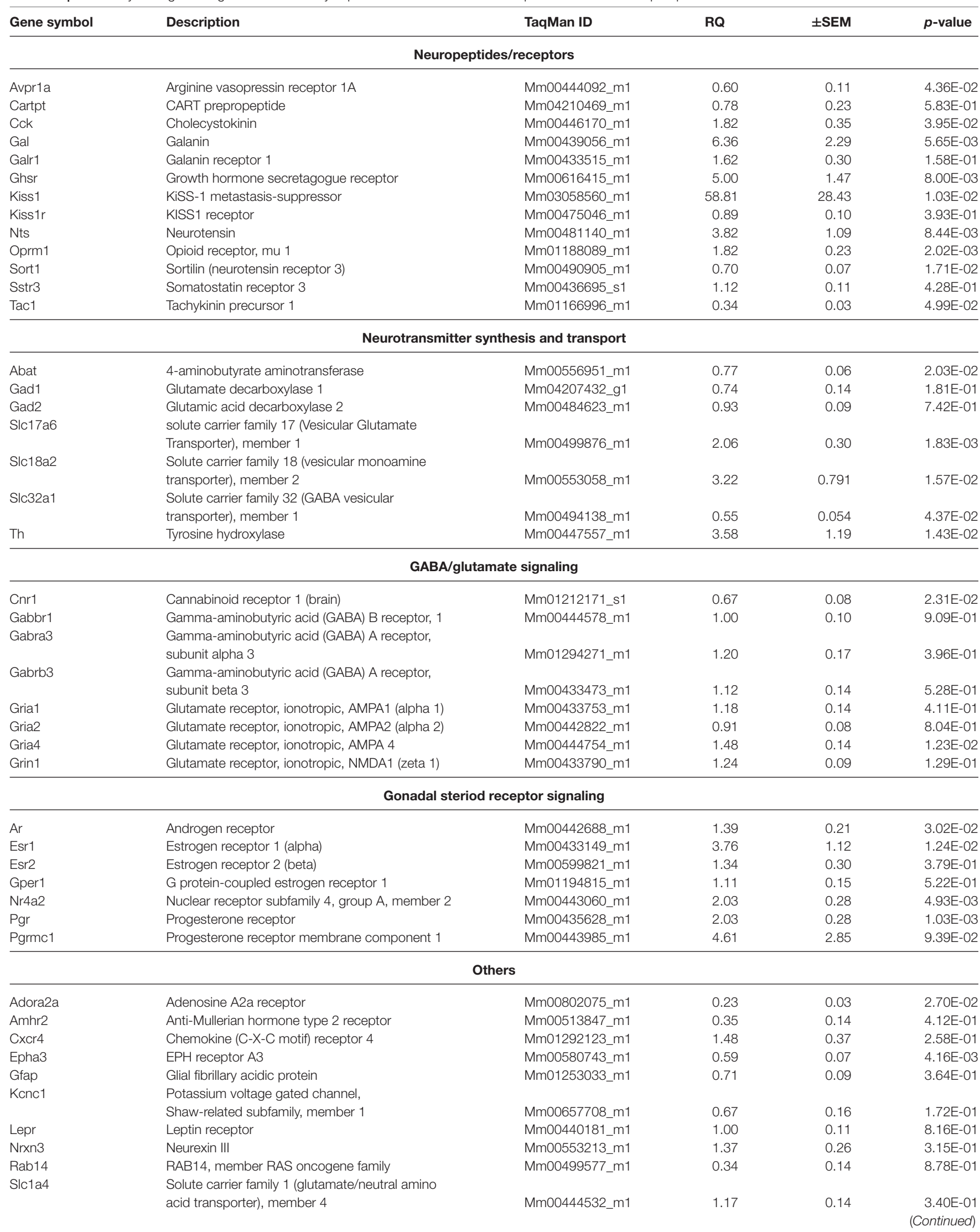


TABLE 1 | Continued

\begin{tabular}{|c|c|c|c|c|c|}
\hline Gene symbol & Description & TaqMan ID & $\mathbf{R Q}$ & \pm SEM & $p$-value \\
\hline Ucp2 & Uncoupling protein 2 (mitochondrial, proton carrier) & Mm00627599_m1 & 1.30 & 0.08 & 1.69E-02 \\
\hline
\end{tabular}

Forty-eight target genes were selected and grouped in neuropeptides/receptors, neurotransmitter synthesis and transport, GABA/glutamate signaling, gonadal steroid receptor signaling and others categories. Relative quantity (RQ), standard error of the mean (SEM) and p-value are given for each studied gene. Expression of 24 genes reached the level of significance $(p<0.05$; Student's $t$-test $)$.

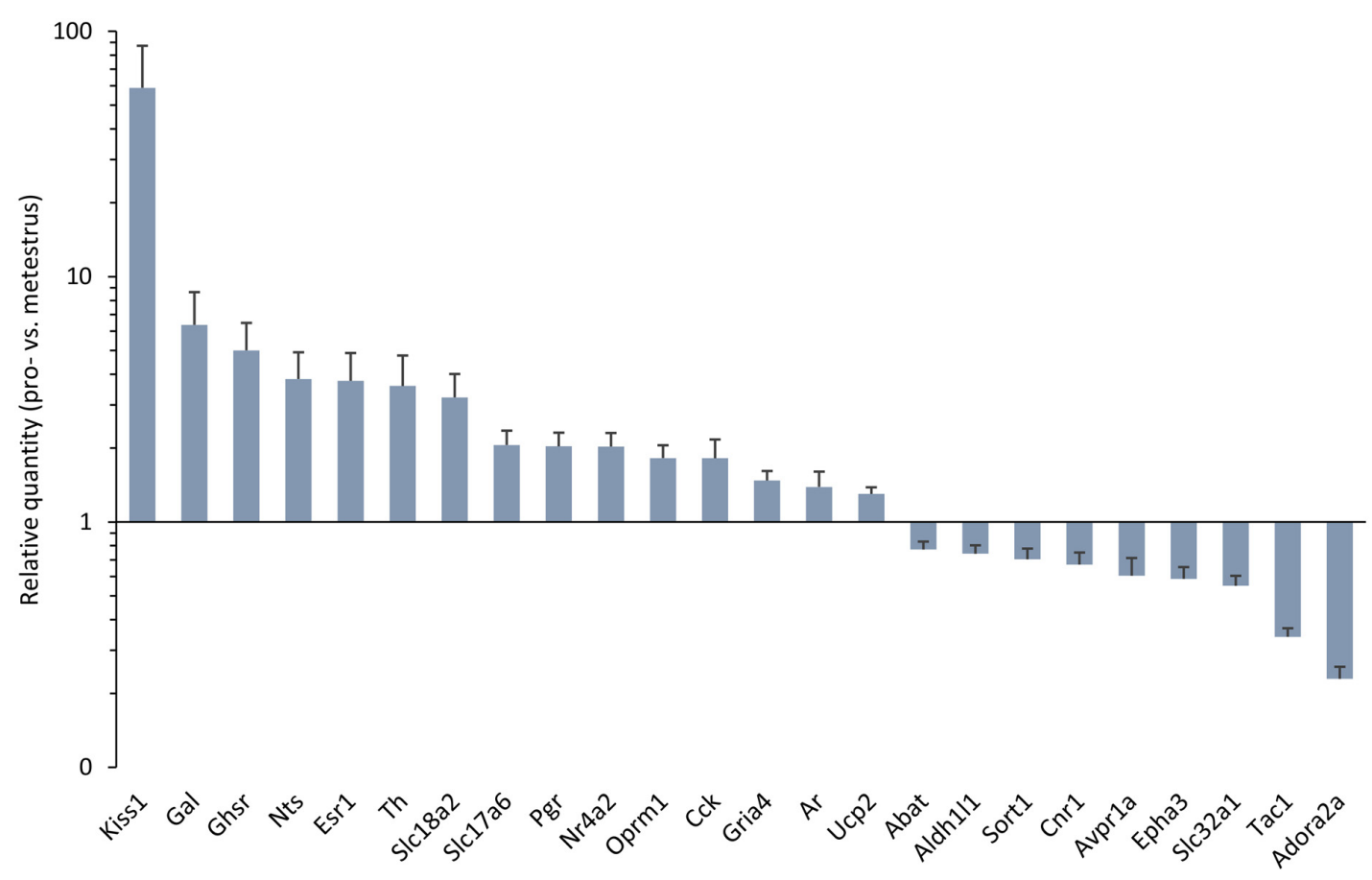

FIGURE 1 | Differentially expressed genes in the antero-ventral periventricular/medial preoptic area (MPOA) of the late proestrous mouse. Relative quantity (RQ) values indicate the relative expression of genes in the pro- vs. metestrous experimental groups ( $p<0.05$, Student's $t$-test). $R Q$ values are visualized as a graph with $\log 10$ scale on the $y$ axis.

\section{Network Analysis of Differentially Expressed Genes}

The list of differentially expressed genes was uploaded to a web resource (String $10.5^{1}$ ) for the analysis of known or predicted functional protein-protein interactions between proteins encoded by these genes. The scores of evidences were scaled from 0 (insignificant) to 1 in the categories as follows: neighborhood in the genome, gene fusions, co-occurrence across genomes, co-expression, experimental/biochemical data, association in curated databases and co-mentioning in PubMed abstracts. A combined score was calculated from the individual scores for each interaction. The interactions were visualized using the confidence view where connecting line thickness indicate the strength of data support. The non-hierarchical $k$-means clustering method was performed by the String.

\footnotetext{
${ }^{1}$ https://www.string-db.org
}

\section{RESULTS}

\section{Network Visualization of Genes by STRING}

The $k$-means clustering view of the predicted interactions among proteins encoded by the 48 target genes whose differential expression was studied are depicted in Supplementary Figure S1. The selection criteria of the 48 genes were based their known or supposed function in the regulation of the AVPV/MPOA and the estrous cycle. The official gene symbols and names are shown in Table 1.

\section{Differential Expression of Genes in the AVPV/MPOA of Proestrous vs. Metestrous Mice}

\section{Neuropeptides and Peptide Receptors}

Gene expression of neuropeptides and peptide receptors changed significantly $(p<0.05$, Student's $t$-test) at late proestrus 
compared to metestrus mice in the same period of the day. In proestrus, the relative quantity (rq; proestrus vs. metestrus) of genes increased as follows: kiss-1 metastasis-suppressor (Kiss1; rq $58.81 \pm 28.43$ ), galanin (Gal; rq $6.36 \pm 2.29$ ) growth hormone secretagogue receptor (Ghsr; rq $5.00 \pm 1.47$ ), neurotensin (Nts; rq $3.82 \pm 1.09$ ), cholecystokinin (Cck; rq $1.82 \pm 0.35)$, opioid receptor mu 1 (Oprm1; rq $1.82 \pm 0.23)$. Expression of arginine vasopressin receptor 1A (Avpr1a; rq $0.60 \pm 0.11)$, tachykinin precursor 1 (Tac1; rq $0.34 \pm 0.03$ ) and sortilin/NT receptor 3 (Sort1; rq $0.70 \pm 0.07$ ) decreased in proestrus (Table $\mathbf{1}$ and Figure 1). No significant change has been detected in the expression of the Kiss1 receptor (Kiss1r), somatostatin receptor 3 (Sstr3), CART prepropeptide (Cartpt) and galanin receptor 1 (Galr1; Table 1).

\section{Neurotransmitter Synthesis and Transport; GABA and Glutamate Signaling}

Expression of the L-DOPA synthetizing enzyme tyrosine hydroxylase ( $T h ;$ rq $3.58 \pm 1.19$ ), the vesicular monoamine transporter 2 (Slc18a2; rq $3.22 \pm 0.791$ ), and the vesicular glutamate transporter 2 (Slc17a6; rq $2.06 \pm 0.30)$ was increased in proestrus. On the contrary, decreased mRNA levels of the 4 -aminobutyrate aminotransferase (Abat; rq $0.77 \pm 0.06$ ) and the GABA vesicular transporter 1 (Slc32a1; rq $0.55 \pm 0.054$ ) were measured in the proestrous mice. Expression of genes encoding GABA and glutamate receptor subunits (Gabbr1, Gabra3, Gabrb3, Gria1, Gria2, Grin1) remained unchanged across the comparison of the two groups, apart from the ionotropic glutamate receptor AMPA4 (Gria4) that showed an

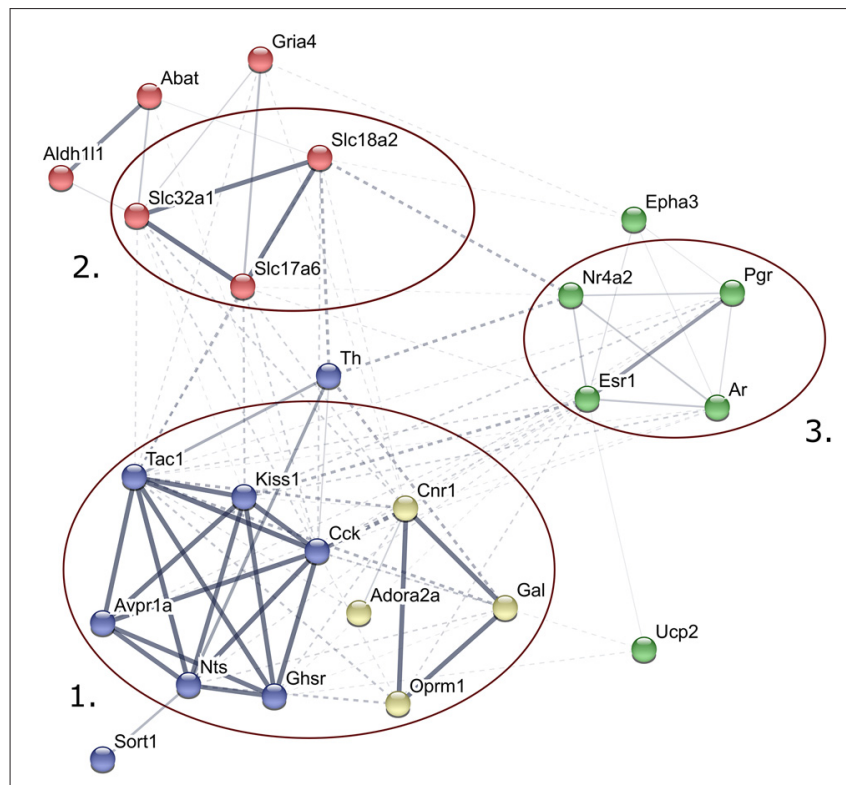

FIGURE 2 | Predicted interactions among proteins encoded by genes expressed differentially in late proestrus. Network visualization of the differentially expressed proteins was achieved by STRING v10 (http://string-db.org). The clusters of neuropeptides/neuropeptide receptors coupled to G proteins (1), solute carrier proteins involved in synaptic vesicle cycle (2) gonadal steroid hormone signaling pathway (3) are prominent. increased mRNA level (rq $1.48 \pm 0.14$ ) in proestrus (Table 1 and Figure 1).

\section{Gonadal Steroid Receptor Signaling}

The estrogen receptor alpha (Esr1, rq $3.76 \pm 1.12$ ), the progesterone receptor (Pgr; rq $2.03 \pm 0.28)$, the transcriptionallyinducible nuclear receptor $(\mathrm{Nr} 4 a 2, \mathrm{rq} 2.03 \pm 0.28)$ and the androgen receptor $(A r ; \mathrm{rq} 1.39 \pm 0.21)$ were all upregulated in proestrus (Table 1 and Figure 1). The expression level of the estrogen receptor beta (Esr2), the G protein-coupled estrogen receptor (Gper1) and the progesterone receptor membrane component 1 (Pgrmc1) did not change significantly (Table 1).

\section{Others}

Expression of the uncoupling protein $2(U c p 2, \mathrm{rq} 1.3 \pm 0.08)$ gene was increased, whereas the adenosine A2a receptor (Adora2a; rq $0.23 \pm 0.03$ ), the ephrin type-a receptor 3 (Epha3; rq $0.59 \pm 0.07$ ) and the cannabinoid receptor $1(C n r 1$; rq $0.67 \pm 0.08)$ showed significant downregulated mRNA levels in proestrus (Table $\mathbf{1}$ and Figure 1). The change was not significant in the mRNA levels of the following targets: Amhr2, Cxcr4, Gfap, Kcnc1, Lepr, Nrxn3, Rab14, Slc1a4 and Slc25a4 (Table 1).

\section{Putative Interactions of Proteins Encoded by the Differentially Expressed Genes}

STRING v10 database and web resource (Szklarczyk et al., 2015) allowed an interactive network visualization of proteins encoded by the 24 genes regulated differentially in proestrus (Figure 2). The footprint of proestrus was represented in protein clusters as follows: neuropeptides and neuropeptide receptors coupled to G proteins (score $>0.9$ in the Reactome pathways "G alpha $(q)$ " and "G alpha (i) signaling events"), solute carrier family members (score: $>0.88$ in the KEGG pathway "synaptic vesicle cycling") and nuclear gonadal steroid hormone receptors (combined score 0.24-0.69; enriched in GO:0043401 termed as "steroid hormone mediated signaling pathway"). Networking of individual proteins and the established protein clusters was observed.

\section{Localization of Kisspeptin, Galanin, Cholecystokinin and Tyrosine Hydroxylase Immunoreactive Structures in the AVPV/MPOA of the Proestrous Mouse}

Expression of KP, GAL, CCK and $\mathrm{TH}$ were visualized by fluorescent immunocytochemistry in the main representative compartments of the periventricular zone in proestrous mice (Figure 3). GAL was not detectable in any perikarya, only the axons displayed GAL immunoreactivity. KP, CCK and TH were present in cell bodies located around the 3rd ventricle and in the vicinity of the vascular organ of lamina terminalis (OVLT), as well as in fine neuronal processes scattered in the medial (MPOM) and lateral (MPOL) divisions of the medial preoptic nucleus. 

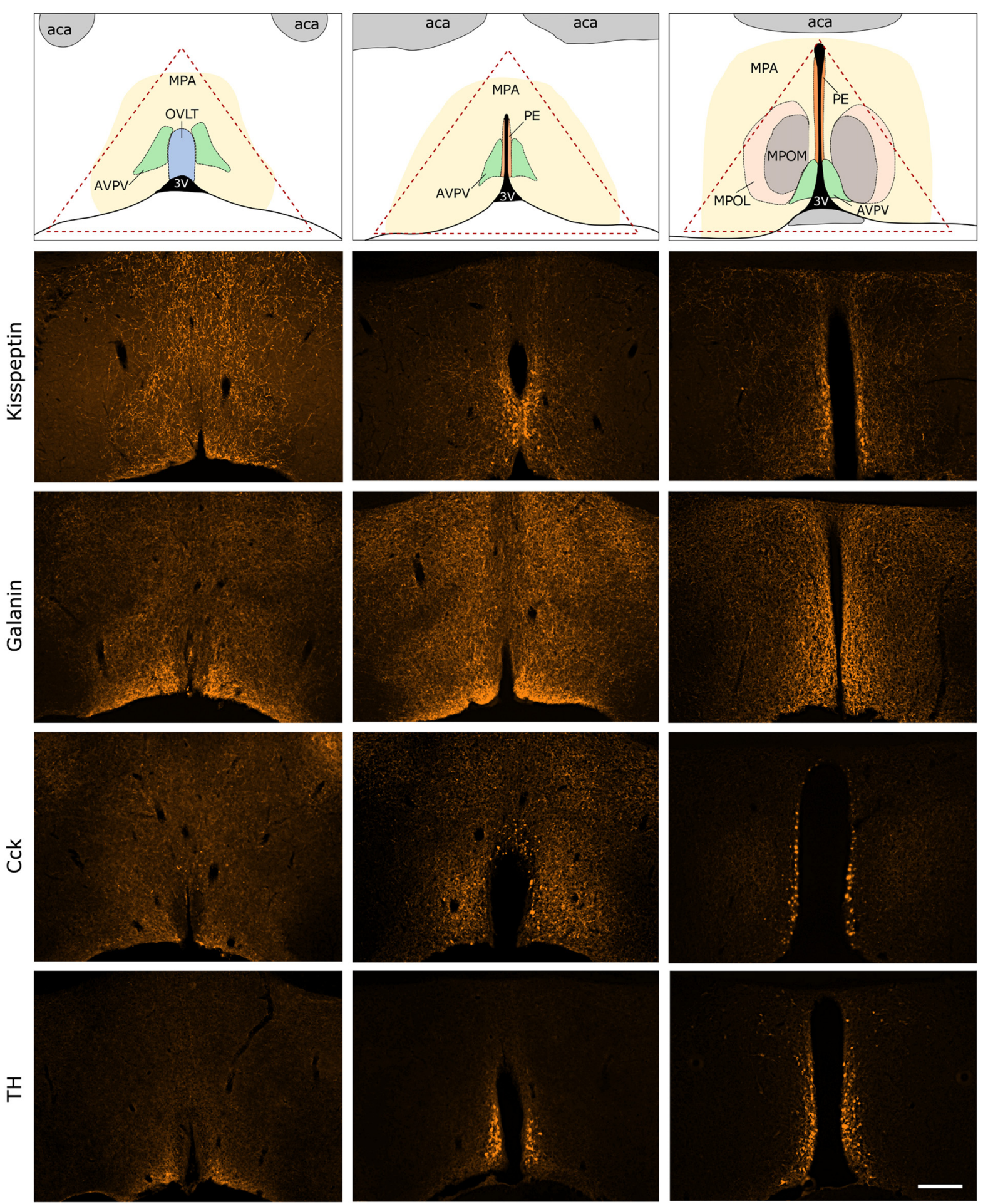

FIGURE 3 | Immunocytochemical localization of kisspeptin (KP), galanin (GAL), cholecystokinin (CCK) and tyrosine-hydroxylase (TH) in the antero-ventral periventricular/MPA of the proestrous mouse. The uppermost row illustrates the MPA and its subdivisions in three representative rostro-caudal planes (from left to right). Red triangle indicates the border lines of tissue area sampled for the real-time PCR study. Immunofluorescent detection of KP, galanin, CCK and TH is provided in the three, representative frontal planes. KP, CCK and TH appear in cell bodies within the AVPV and the periventricular nucleus (PE) in addition to neuronal processes. Galanin-immunoreactivity is not detectable at the level of perikarya in proestrous mouse, despite its intense occurrence in axons. aca, anterior commissure; AVPV, antero-ventral periventricular nucleus; MPOM, medial division of the medial preoptic nucleus; MPOL, lateral division of the medial preoptic nucleus; OVLT, vascular organ of lamina terminalis; 3V, 3rd ventricle. Scale bar: $200 \mu \mathrm{m}$. 


\section{DISCUSSION}

\section{Altered Expression of Genes Encoding Neuropeptides in the AVPV/MPOA of Proestrous Mice}

The comparison of the AVPV/MPOA in met- and proestrous mice revealed the differential expression of Kiss1, Gal, Nts and $C c k$ genes with a marked upregulation in proestrus. The increment in RQ of mRNAs was the highest for Kiss1 (58.81), followed by Gal (6.36) and Nts (3.82), whereas Cck showed a weaker response (1.82). The downregulation of tachykinin precursor 1 (Tac1) suggests a declining SP production at late proestrus. Neuropeptides encoded by these genes have previously been mapped in the rostral periventricular region of the rodent brain (Simerly and Swanson, 1987; Smith and Wise, 2001; Clarkson and Herbison, 2006; Dungan et al., 2006; Ducret et al., 2010; Porteous et al., 2011; Overgaard et al., 2013; Skrapits et al., 2015). Axons arising from KP neurons of the AVPV innervate GnRH cells in mice (Smith et al., 2005; Kalló et al., 2012; Kumar et al., 2015; Yip et al., 2015) and the released neurohormone exerts an excitatory tone upon them (Han et al., 2005; Clarkson et al., 2008; Liu et al., 2011). These KP neurons also process the positive E2 feedback signal (Gottsch et al., 2009; Frazao et al., 2013; Dubois et al., 2015) and therefore, have an unequivocal role in the generation of the preovulatory GnRH-LH surge during proestrus (Dungan et al., 2006; Smith et al., 2006a; Clarkson et al., 2008). GAL is also a potent central regulator of reproduction (Merchenthaler et al., 1990; Lopez et al., 1991; Rajendren, 2002) whose expression is heavily regulated by E2 (Gabriel et al., 1993; Liposits et al., 1995). It is of note that KP neurons can co-synthesize GAL ranging from $7 \%$ seen in intact (Porteous et al., 2011) up to $87 \%$ characterizing ovariectomized, E2 replaced mice (Kalló et al., 2012). CCK synthesis also takes place in the periventricular nucleus of rodents (Simerly and Swanson, 1987; Porteous et al., 2011). In concert, CKK axons communicate with GnRH neurons in the OVLT region via CCK-1 receptors and the neuropeptide modulates their activity (Giacobini and Wray, 2007). The present finding is indicative of an increased CCK production in the MPA of the mouse brain during proestrus. A similar tendency was observed in case of Nts mRNA expression confirming previous reports on the estrous cycle dependent synthesis of NT (Herbison and Theodosis, 1991; Smith and Wise, 2001) in the MPA and its role in induction of the LH surge via interaction with GnRH neurons (Alexander et al., 1989a,b; Dungan Lemko et al., 2010). CCK and NT production is anatomically distinct from KP synthesis in the AVPV region without any sign of co-synthesis (Porteous et al., 2011). SP was shown to be synthesized in the AVPV region (Simerly and Swanson, 1987) and its production regulated by E2 (Okamura et al., 1994).

\section{Influence of Proestrus on Local GABA, Glutamate and Dopamine (DA) Neuronal Systems of the AVPV/MPOA}

Similar to the rich peptidergic character of the AVPV/MPOA of the rodent brain, neurotransmitters are also synthesized herein. Glutamate (Ottem et al., 2004), GABA (Ottem et al., 2004) and DA (Simerly et al., 1997; Clarkson and Herbison, 2011) production takes place in its neurons. Neurons with dual glutamate/GABA phenotype have been identified in the area in both rats (Ottem et al., 2004) and mice (Cravo et al., 2011). These neurons also express estrogen receptors (Simerly et al., 1997; Merchenthaler et al., 2004; Zuloaga et al., 2014; Cheong et al., 2015) and via rostral projections they innervate GnRH neurons (Boehm et al., 2005). GABA- and glutamate-driven events of neurotransmission onto $\mathrm{GnRH}$ neurons have been the most comprehensively studied regulatory mechanisms of these neurosecretory cells (Christian and Moenter, 2010; Iremonger et al., 2010; Moenter, 2010; Penatti et al., 2010; Liu and Herbison, 2011; Taylor-Burds et al., 2015). A wide repertoire of GABA, glutamate and DA receptors characterizes the GnRH neurons (Todman et al., 2005; Vastagh et al., 2015, 2016), as a prerequisite of their control by neurotransmitters. The upregulation of solute carrier family 17, member 1 gene (Slc17a6) that codes for vesicular glutamate transporter 2 (VGLUT2) indicates the probability of enhanced packaging of glutamate into synaptic vesicles at the level of axon terminals in proestrus. In parallel with this, a differential regulation of the expression of various glutamate receptor mRNAs in GnRH neurons of the proestrous mice has recently been reported (Vastagh et al., 2016). Regarding the local GABA-ergic system, the expression of the GABA synthesizing enzymes (GAD1 and GAD2) did not change prior to the GnRH surge in this study. The status of the vesicular GABA pool in the AVPV/MPOA block was also monitored by the expression of the vesicular GABA transporter (Slc32a1) mRNA that was downregulated. The GABA catabolizing enzyme, 4-aminobutyrate aminotransferase, was slightly downregulated, too. These findings indicate that the medial preoptic GABAergic neuronal system is rather silent a few hours prior to the GnRH surge.

DA synthesis in the AVPV/MPOA has been verified long ago (Simerly and Swanson, 1987). The rate limiting enzyme of DA synthesis, $\mathrm{TH}$, is co-synthesized in about 50 percent of KP neurons in the region (Clarkson and Herbison, 2011). GnRH neurons express DA receptors (Vastagh et al., 2016) and the monoamine regulates their activity (Liu and Herbison, 2013). The increased expression of Th mRNA in late proestrus in neurons of the AVPV/MPOA is indicative of a rising DA synthesis. In addition, the markedly increased expression of vesicular monoamine transporter 2 (Slc18a2) mRNA suggests that packaging of DA into synaptic vesicles within axon terminals that belong to AVPV/MPOA neurons may be accelerated. Both GABA and glutamatergic synaptic transmission mechanisms are regulated via retrograde endocannabinoid signaling utilizing cannabinoid 1 (CB1) receptors residing in the presynaptic terminals (Katona and Freund, 2012). Retrograde endocannabinoid signaling from GnRH neurons toward their GABAergic presynaptic boutons has also been substantiated earlier (Farkas et al., 2010). Therefore, it might have a special importance that $\mathrm{CB} 1$ receptor mRNA expression undergoes downregulation before the zenith of proestrus in the AVPV/MPOA, a main GABA and glutamate supplier of amino acid transmitter receptors of $\mathrm{GnRH}$ neurons. 


\section{Altered Expression of Nuclear Hormone Receptor Genes in the \\ Rostral Periventricular Area}

Gonadal steroid hormones heavily influence the AVPV/MPOA and functions associated with this territory (Ehret and Buckenmaier, 1994; Simerly et al., 1997; Bodo et al., 2006; Kudwa et al., 2006; Nakata et al., 2016). The marked sexual dimorphism of the locus (Davis et al., 1996; Bodo et al., 2006; Kanaya et al., 2014) also exemplifies its sensitivity to gonadal steroids. The classical, estrogen receptor 1(ER-alpha; Simerly et al., 1990; Merchenthaler et al., 2004), the novel subtype, estrogen receptor 2 (ER-beta; Shughrue et al., 1997; Merchenthaler et al., 2004; Zuloaga et al., 2014) and the membrane-associated form GPER1 (Treen et al., 2016) have all been identified and mapped in different structural compartments of the region. Signaling to the region by progesterone and androgen hormones has also been demonstrated and the cellular distribution of their receptors elucidated (Handa et al., 1986; Simerly et al., 1990; Kanaya et al., 2014; Brock et al., 2015). The KP/GABA/glutamate neurons of the region are exceptional targets of gonadal hormones, including E2. During the positive E2 feedback, signaling via ER $\alpha$ seems to be mandatory (Smith et al., 2005; Wintermantel et al., 2006; Frazao et al., 2013; Cheong et al., 2015; Dubois et al., 2015) in KP neurons that become activated (Ducret et al., 2010; Zhang et al., 2013, 2015; Wang et al., 2016). In harmony with these events, we report here the upregulation of Esr1 in late proestrus without any significant change in the expression of the other two estrogen receptors, Esr2 and Gper1. Similarly, the expression of nuclear androgen and PR mRNAs increased. This result supports previous studies reporting the estrous cycle and gonadal hormone dependent expression of progesterone, androgen and alpha type estrogen receptors in this brain region (Handa et al., 1986; Simerly et al., 1996; Intlekofer and Petersen, 2011).

In addition, an orphan nuclear receptor called nuclear receptor related 1 (Nr4a2) also showed an increased expression at late proestrus. It has been shown to act as a transcriptional activator of endogenous TH (Sakurada et al., 1999) and contribute to the well-being of DA neurons in the brainstem. It might also support the activation of the DA neuron cluster of the AVPV during the positive E2 feedback.

\section{Modulation of Peptide and Transmitter Receptor Gene Expression in AVPV/MPOA during Proestrus}

Proestrus had influence on the expression of certain peptide and neurotransmitter receptor mRNAs in the AVPV/MPOA. The upregulated mRNAs included growth hormone secretagogue receptor (Ghsr), $\mu$-opioid receptor (Oprm1) and glutamate receptor subunit (Gria4) indicating that AVPV/MPOA neurons may be more forcefully modulated by ghrelin, endorphin, enkephalin and glutamate signals during proestrus. The expression of adenosine receptor 2a (Adora2a), neurotensin receptor 3 (Sort1) and arginine vasopressin receptor $1 \mathrm{~A}$ (Avprla) mRNAs was markedly downregulated. It has been shown previously, that KP neurons in the AVPV are regulated by ghrelin (Forbes et al., 2009), opioid peptides (Zhang et al., 2013) and glutamate (Ducret et al., 2010). NT delivered onto the preoptic area was reported to influence the GnRH surge in ovariectomized estrogen-primed animals (Akema et al., 1987). Arginine vasopressin signaling via V1a receptors to the MPA of rat has been explored previously (Kalamatianos et al., 2004) finding the upregulation of the receptor expression by E2 in ovariectomized animals. In our mouse study, at late proestrus the V1a receptor mRNA undergoes downregulation.

\section{Effect of Proestrus on Other Regulatory Mechanisms in the AVPV/MPOA}

Proestrus also resulted in altered expression of uncoupling protein 2 (mitochondrial, proton carrier, Ucp2). Upregulation of its mRNA implies that E2 may control mitochondriaderived reactive oxygen species generation (Paradis et al., 2003) and lipid metabolism (Dulloo and Samec, 2001) in the AVPV. The downregulation of ephrin receptor a3 (Epha3) in the AVPV/MPOA might reflect changes in communication between neurons and astrocytes (Murai and Pasquale, 2011). The differential expression at proestrus and the physiological role of adenosine receptor 2a (Adora2a) in the AVPV/MPOA await further elucidation. Aldehyde dehydrogenase 1 family, member L1 gene (Aldh1L1) showed a delicate down-regulation, that among others, may mirror the influence of the late proestrus specific hormonal milieu upon astrocytes (Cahoy et al., 2008).

\section{Predicted Interactions Among Proteins Encoded by Genes Expressed Differentially in Proestrus}

The STRING v10 database and web resource was applied to demonstrate the predicted interactions of proteins encoded by the 24 genes regulated differentially in proestrus and the 48 genes analyzed in the study. This tool provided a functional interpretation of the altered gene expression via conversion of gene lists into coherent networks of genes in which edges (interactions) are scored depending on current evidences. Enrichment of higher scored edges form gene clusters. Differentially expressed genes were represented in G protein-coupled signaling, gonadal steroid signaling and synaptic vesicle cycling pathways. Although these clusters were already represented in the 48-gene network, their strengthening in the network of the differentially expressed genes may indicate the robustness and significance of changes in the synaptic transmission (signal transductions, vesicle cycling) and steroid hormone signaling in the AVPV during proestrus.

\section{Distribution of Neuropeptide/Transmitter System Specific Proteins in the AVPV/MPOA of the Proestrous Mice}

The immunocytochemical study revealed the rostro-caudal distribution of KP, GAP, CCK and TH immunoreactive (IR) perikarya and neuronal fibers in the AVPV/MPOA of intact, late proestrous mice. The overall anatomical topography of these 
systems corresponds to previously published data (Simerly and Swanson, 1987; Clarkson and Herbison, 2011; Porteous et al., 2011). KP, CCK and TH immunoreactivities appeared in cell bodies of proestrous mice and the intensity of staining resembled images generated from either colchicine-treated (Porteous et al., 2011) or ovariectomized plus E2-replaced (Kalló et al., 2012) mice. In contrast, proestrus did not allow the proper visualization of galanin-synthesizing perikarya in the region despite the known estrogen-dependent expression of the neurohormone. While the labeled neurohormone producing cells occupy mainly the rostral periventricular zone, the IR neuronal processes course laterally and heavily infiltrate the entire region. The selected morphological images also exemplify that proteins, encoded by genes regulated differentially in proestrus, are expressed in the AVPV/MPOA dissected for PCR analysis.

\section{CONCLUSION}

The present study provided evidence for altered expression of genes in the AVPV/MPOA of intact mice at late proestrus. We identified KP, galanin, NT, CCK, substance $\mathrm{P}$ as peptide, likewise, glutamate, DA and GABA as transmitter-specific phenotypes of the proestrus-regulated neurons within the region. The participation of $\mathrm{ER} \alpha$ in the process strengthens further the role of the changing estrogen milieu during proestrus in the transcriptional activation of neuron assemblies of the

\section{REFERENCES}

Adachi, S., Yamada, S., Takatsu, Y., Matsui, H., Kinoshita, M., Takase, K., et al. (2007). Involvement of anteroventral periventricular metastin/kisspeptin neurons in estrogen positive feedback action on luteinizing hormone release in female rats. J. Reprod. Dev. 53, 367-378. doi: 10.1262/jrd.18146

Akema, T., Praputpittaya, C., and Kimura, F. (1987). Effects of preoptic microinjection of neurotensin on luteinizing hormone secretion in unanesthetized ovariectomized rats with or without estrogen priming. Neuroendocrinology 46, 345-349. doi: 10.1159/000124843

Akther, S., Fakhrul, A. A., and Higashida, H. (2014). Effects of electrical lesions of the medial preoptic area and the ventral pallidum on mate-dependent paternal behavior in mice. Neurosci. Lett. 570, 21-25. doi: 10.1016/j. neulet.2014.03.078

Alexander, M. J., Dobner, P. R., Miller, M. A., Bullock, B. P., Dorsa, D. M., and Leeman, S. E. (1989a). Estrogen induces neurotensin/neuromedin N messenger ribonucleic acid in a preoptic nucleus essential for the preovulatory surge of luteinizing hormone in the rat. Endocrinology 125, 2111-2117. doi: 10.1210/endo-125-4-2111

Alexander, M. J., Mahoney, P. D., Ferris, C. F., Carraway, R. E., and Leeman, S. E. (1989b). Evidence that neurotensin participates in the central regulation of the preovulatory surge of luteinizing hormone in the rat. Endocrinology 124, 783-788. doi: 10.1210/endo-124-2-783

Barr, G. D., and Barraclough, C. A. (1978). Temporal changes in medial basal hypothalamic LH-RH correlated with plasma $\mathrm{LH}$ during the rat estrous cycle and following electrochemical stimulation of the medial preoptic area in pentobarbital-treated proestrous rats. Brain Res. 148, 413-423. doi: 10.1016/0006-8993(78)90729-1

Bodo, C., Kudwa, A. E., and Rissman, E. F. (2006). Both estrogen receptor- $\alpha$ and $-\beta$ are required for sexual differentiation of the anteroventral periventricular area in mice. Endocrinology 147, 415-420. doi: 10.1210/en.2005-0834

Boehm, U., Zou, Z., and Buck, L. B. (2005). Feedback loops link odor and pheromone signaling with reproduction. Cell 123, 683-695. doi: 10.1016/j.cell. 2005.09.027
AVPV/MPOA that have a fundamental contribution to the surge release of $\mathrm{GnRH}$.

\section{AUTHOR CONTRIBUTIONS}

CV performed the experiments, analyzed the data and wrote the manuscript. ZL designed the experiments, supervised the project and wrote the manuscript.

\section{FUNDING}

This work was supported by the Hungarian Scientific Research Fund (OTKA K100722 and OTKA 115984).

\section{ACKNOWLEDGMENTS}

Authors wish to express their gratitude to Drs. A. Caraty (France) and P. Ciofi (France) for the generous donation of the primary antibodies.

\section{SUPPLEMENTARY MATERIAL}

The Supplementary Material for this article can be found online at: http://journal.frontiersin.org/article/10.3389/fncel. 2017.00183/full\#supplementary-material

Brock, O., De Mees, C., and Bakker, J. (2015). Hypothalamic expression of oestrogen receptor $\alpha$ androgen receptor is sex-, age- and region-dependent in mice. J. Neuroendocrinol. 27, 264-276. doi: 10.1111/jne.12258

Byers, S. L., Wiles, M. V., Dunn, S. L., and Taft, R. A. (2012). Mouse estrous cycle identification tool and images. PLoS One 7:e35538. doi: 10.1371/journal.pone 0035538

Cahoy, J. D., Emery, B., Kaushal, A., Foo, L. C., Zamanian, J. L. Christopherson, K. S., et al. (2008). A transcriptome database for astrocytes, neurons and oligodendrocytes: a new resource for understanding brain development and function. J. Neurosci. 28, 264-278. doi: 10.1523/JNEUROSCI. 4178-07.2008

Cheong, R. Y., Czieselsky, K., Porteous, R., and Herbison, A. E. (2015). Expression of ESR1 in glutamatergic and GABAergic neurons is essential for normal puberty onset, estrogen feedback and fertility in female mice. J. Neurosci. 35, 14533-14543. doi: 10.1523/JNEUROSCI.1776-15.2015

Christian, C. A., Glidewell-Kenney, C., Jameson, J. L., and Moenter, S. M. (2008). Classical estrogen receptor $\alpha$ signaling mediates negative and positive feedback on gonadotropin-releasing hormone neuron firing. Endocrinology 149, 5328-5334. doi: 10.1210/en.2008-0520

Christian, C. A., and Moenter, S. M. (2010). The neurobiology of preovulatory and estradiol-induced gonadotropin-releasing hormone surges. Endocr. Rev. 31, 544-577. doi: 10.1210/er.2009-0023

Ciofi, P., and Tramu, G. (1990). Distribution of cholecystokinin-likeimmunoreactive neurons in the guinea pig forebrain. J. Comp. Neurol. 300, 82-112. doi: 10.1002/cne.903000107

Clarkson, J., d'Anglemont de Tassigny, X., Moreno, A. S., Colledge, W. H., and Herbison, A. E. (2008). Kisspeptin-GPR54 signaling is essential for preovulatory gonadotropin-releasing hormone neuron activation and the luteinizing hormone surge. J. Neurosci. 28, 8691-8697. doi: 10.1523/JNEUROSCI.1775-08.2008

Clarkson, J., and Herbison, A. E. (2006). Postnatal development of kisspeptin neurons in mouse hypothalamus; sexual dimorphism and projections to gonadotropin-releasing hormone neurons. Endocrinology 147, 5817-5825. doi: 10.1210/en.2006-0787 
Clarkson, J., and Herbison, A. E. (2009). Oestrogen, kisspeptin, GPR54 and the pre-ovulatory luteinising hormone surge. J. Neuroendocrinol. 21, 305-311. doi: 10.1111/j.1365-2826.2009.01835.x

Clarkson, J., and Herbison, A. E. (2011). Dual phenotype kisspeptin-dopamine neurones of the rostral periventricular area of the third ventricle project to gonadotrophin-releasing hormone neurones. J. Neuroendocrinol. 23, 293-301. doi: 10.1111/j.1365-2826.2011.02107.x

Cora, M. C., Kooistra, L., and Travlos, G. (2015). Vaginal cytology of the laboratory rat and mouse: review and criteria for the staging of the estrous cycle using stained vaginal smears. Toxicol. Pathol. 43, 776-793. doi: 10.1177/0192623315570339

Cravo, R. M., Margatho, L. O., Osborne-Lawrence, S., Donato, J. Jr., Atkin, S., Bookout, A. L., et al. (2011). Characterization of Kiss1 neurons using transgenic mouse models. Neuroscience 173, 37-56. doi: 10.1016/j. neuroscience.2010.11.022

Czieselsky, K., Prescott, M., Porteous, R., Campos, P., Clarkson, J., Steyn, F. J., et al. (2016). Pulse and surge profiles of luteinizing hormone secretion in the mouse. Endocrinology 157, 4794-4802. doi: 10.1210/en.2016-1351

Davis, E. C., Shryne, J. E., and Gorski, R. A. (1996). Structural sexual dimorphisms in the anteroventral periventricular nucleus of the rat hypothalamus are sensitive to gonadal steroids perinatally, but develop peripubertally. Neuroendocrinology 63, 142-148. doi: 10.1159/000126950

Dubois, S. L., Acosta-Martinez, M., DeJoseph, M. R., Wolfe, A., Radovick, S., Boehm, U., et al. (2015). Positive, but not negative feedback actions of estradiol in adult female mice require estrogen receptor $\alpha$ in kisspeptin neurons. Endocrinology 156, 1111-1120. doi: 10.1210/en.2014-1851

Ducret, E., Gaidamaka, G., and Herbison, A. E. (2010). Electrical and morphological characteristics of anteroventral periventricular nucleus kisspeptin and other neurons in the female mouse. Endocrinology 151, 2223-2232. doi: 10.1210/en.2009-1480

Dulloo, A. G., and Samec, S. (2001). Uncoupling proteins: their roles in adaptive thermogenesis and substrate metabolism reconsidered. Br. J. Nutr. 86, 123-139. doi: 10.1079/bjn2001412

Dungan, H. M., Clifton, D. K., and Steiner, R. A. (2006). Minireview: kisspeptin neurons as central processors in the regulation of gonadotropin-releasing hormone secretion. Endocrinology 147, 1154-1158. doi: 10.1210/en.2005-1282

Dungan Lemko, H. M., Naderi, R., Adjan, V., Jennes, L. H., Navarro, V. M., Clifton, D. K., et al. (2010). Interactions between neurotensin and GnRH neurons in the positive feedback control of $\mathrm{GnRH} / \mathrm{LH}$ secretion in the mouse. Am. J. Physiol. Endocrinol. Metab. 298, E80-E88. doi: 10.1152/ajpendo. 00380.2009

Ehret, G., and Buckenmaier, J. (1994). Estrogen-receptor occurrence in the female mouse brain: effects of maternal experience, ovariectomy, estrogen and anosmia. J. Physiol. Paris 88, 315-329. doi: 10.1016/0928-4257(94) 90012-4

Farkas, I., Kalló, I., Deli, L., Vida, B., Hrabovszky, E., Fekete, C., et al. (2010). Retrograde endocannabinoid signaling reduces GABAergic synaptic transmission to gonadotropin-releasing hormone neurons. Endocrinology 151, 5818-5829. doi: 10.1210/en.2010-0638

Farkas, I., Vastagh, C., Sarvari, M., and Liposits, Z. (2013). Ghrelin decreases firing activity of gonadotropin-releasing hormone $(\mathrm{GnRH})$ neurons in an estrous cycle and endocannabinoid signaling dependent manner. PLoS One 8:e78178. doi: 10.1371/journal.pone.0078178

Forbes, S., Li, X. F., Kinsey-Jones, J., and O’Byrne, K. (2009). Effects of ghrelin on Kisspeptin mRNA expression in the hypothalamic medial preoptic area and pulsatile luteinising hormone secretion in the female rat. Neurosci. Lett. 460, 143-147. doi: 10.1016/j.neulet.2009.05.060

Frazao, R., Cravo, R. M., Donato, J. Jr., Ratra, D. V., Clegg, D. J., Elmquist, J. K., et al. (2013). Shift in Kiss1 cell activity requires estrogen receptor $\alpha$. J. Neurosci. 33, 2807-2820. doi: 10.1523/jneurosci.1610-12.2013

Gabriel, S. M., Koenig, J. I., and Washton, D. L. (1993). Estrogen stimulation of galanin gene expression and galanin-like immunoreactivity in the rat and its blockade by the estrogen antagonist keoxifene (LY156758). Regul. Pept. 45, 407-419. doi: 10.1016/0167-0115(93)90367-h

Giacobini, P., and Wray, S. (2007). Cholecystokinin directly inhibits neuronal activity of primary gonadotropin-releasing hormone cells through cholecystokinin-1 receptor. Endocrinology 148, 63-71. doi: 10.1210/en. 2006-0758
Gottsch, M. L., Navarro, V. M., Zhao, Z., Glidewell-Kenney, C., Weiss, J., Jameson, J. L., et al. (2009). Regulation of Kiss1 and dynorphin gene expression in the murine brain by classical and nonclassical estrogen receptor pathways. J. Neurosci. 29, 9390-9395. doi: 10.1523/JNEUROSCI.0763-09.2009

Gu, G. B., and Simerly, R. B. (1997). Projections of the sexually dimorphic anteroventral periventricular nucleus in the female rat. J. Comp. Neurol. 384, 142-164. doi: 10.1002/(sici)1096-9861(19970721)384:1<142::aid-cne9>3. 0. co;2-1

Han, S. K., Abraham, I. M., and Herbison, A. E. (2002). Effect of GABA on GnRH neurons switches from depolarization to hyperpolarization at puberty in the female mouse. Endocrinology 143, 1459-1466. doi: 10.1210/endo. 143.4.8724

Han, S. K., Gottsch, M. L., Lee, K. J., Popa, S. M., Smith, J. T., Jakawich, S. K., et al. (2005). Activation of gonadotropin-releasing hormone neurons by kisspeptin as a neuroendocrine switch for the onset of puberty. J. Neurosci. 25, 11349-11356. doi: 10.1523/JNEUROSCI. 3328-05.2005

Handa, R. J., Reid, D. L., and Resko, J. A. (1986). Androgen receptors in brain and pituitary of female rats: cyclic changes and comparisons with the male. Biol. Reprod. 34, 293-303. doi: 10.1095/biolreprod34.2.293

Herbison, A. E., and Theodosis, D. T. (1991). Neurotensinlmmunoreactive neurons in the rat medial preoptic area are oestrogenreceptive. J. Neuroendocrinol. 3, 587-589. doi: 10.1111/j.1365-2826. 1991.tb00322.x

Hull, E. M., and Dominguez, J. M. (2007). Sexual behavior in male rodents. Horm Behav. 52, 45-55. doi: 10.1016/j.yhbeh.2007.03.030

Intlekofer, K. A., and Petersen, S. L. (2011). 17 $\beta$-estradiol and progesterone regulate multiple progestin signaling molecules in the anteroventral periventricular nucleus, ventromedial nucleus and sexually dimorphic nucleus of the preoptic area in female rats. Neuroscience 176, 86-92. doi: 10.1016/j. neuroscience.2010.12.033

Iremonger, K. J., Constantin, S., Liu, X., and Herbison, A. E. (2010). Glutamate regulation of GnRH neuron excitability. Brain Res. 1364, 35-43. doi: 10.1016/j. brainres.2010.08.071

Kalamatianos, T., Kalló, I., Goubillon, M. L., and Coen, C. W. (2004). Cellular expression of V1a vasopressin receptor mRNA in the female rat preoptic area: effects of oestrogen. J. Neuroendocrinol. 16, 525-533. doi: 10.1111/j.1365-2826. 2004.01199.x

Kalló, I., Vida, B., Deli, L., Molnár, C. S., Hrabovszky, E., Caraty, A., et al. (2012). Co-localisation of kisspeptin with galanin or neurokinin B in afferents to mouse GnRH neurones. J. Neuroendocrinol. 24, 464-476. doi: 10.1111/j.1365-2826. 2011.02262.x

Kanaya, M., Tsuda, M. C., Sagoshi, S., Nagata, K., Morimoto, C., Thu, C. K., et al. (2014). Regional difference in sex steroid action on formation of morphological sex differences in the anteroventral periventricular nucleus and principal nucleus of the bed nucleus of the stria terminalis. PLoS One 9:e112616. doi: 10.1371/journal.pone.0112616

Katona, I., and Freund, T. F. (2012). Multiple functions of endocannabinoid signaling in the brain. Annu. Rev. Neurosci. 35, 529-558. doi: 10.1146/annurevneuro-062111-150420

Kudwa, A. E., Gustafsson, J. A., and Rissman, E. F. (2004). Estrogen receptor $\beta$ modulates estradiol induction of progestin receptor immunoreactivity in male, but not in female, mouse medial preoptic area. Endocrinology 145, 4500-4506. doi: 10.1210/en.2003-1708

Kudwa, A. E., Michopoulos, V., Gatewood, J. D., and Rissman, E. F. (2006). Roles of estrogen receptors $\alpha$ and $\beta$ in differentiation of mouse sexual behavior. Neuroscience 138, 921-928. doi: 10.1016/j.neuroscience. 2005.10.018

Kumar, D., Candlish, M., Periasamy, V., Avcu, N., Mayer, C., and Boehm, U. (2015). Specialized subpopulations of kisspeptin neurons communicate with GnRH neurons in female mice. Endocrinology 156, 32-38. doi: 10.1210/en. 2014-1671

Lee, A. W., and Brown, R. E. (2002). Medial preoptic lesions disrupt parental behavior in both male and female California mice (Peromyscus californicus). Behav. Neurosci. 116, 968-975. doi: 10.1037/0735-7044. 116.6 .968

Liposits, Z., Reid, J. J., Negro-Vilar, A., and Merchenthaler, I. (1995). Sexual dimorphism in copackaging of luteinizing hormone-releasing hormone 
and galanin into neurosecretory vesicles of hypophysiotrophic neurons: estrogen dependency. Endocrinology 136, 1987-1992. doi: 10.1210/en. 136.5 .1987

Liu, X., and Herbison, A. E. (2011). Estrous cycle- and sex-dependent changes in pre- and postsynaptic GABAB control of GnRH neuron excitability. Endocrinology 152, 4856-4864. doi: 10.1210/en.2011-1369

Liu, X., and Herbison, A. E. (2013). Dopamine regulation of gonadotropinreleasing hormone neuron excitability in male and female mice. Endocrinology 154, 340-350. doi: 10.1210/en.2012-1602

Liu, X., Porteous, R., d'Anglemont de Tassigny, X., Colledge, W. H., Millar, R., Petersen, S. L., et al. (2011). Frequency-dependent recruitment of fast amino acid and slow neuropeptide neurotransmitter release controls gonadotropin-releasing hormone neuron excitability. J. Neurosci. 31, 2421-2430. doi: 10.1523/JNEUROSCI.5759-10.2011

Livak, K. J., and Schmittgen, T. D. (2001). Analysis of relative gene expression data using real-time quantitative PCR and the $2^{-\Delta \Delta \mathrm{Ct}}$ Method. Methods 25 , 402-408. doi: 10.1006/meth.2001.1262

Lopez, F. J., Merchenthaler, I., Ching, M., Wisniewski, M. G., and Negro-Vilar, A. (1991). Galanin: a hypothalamic-hypophysiotropic hormone modulating reproductive functions. Proc. Natl. Acad. Sci. U S A 88, 4508-4512. doi: $10.1073 /$ pnas.88.10.4508

McHenry, J. A., Otis, J. M., Rossi, M. A., Robinson, J. E., Kosyk, O., Miller, N. W., et al. (2017). Hormonal gain control of a medial preoptic area social reward circuit. Nat. Neurosci. 20, 449-458. doi: 10.1038/nn.4487

Merchenthaler, I., Lane, M. V., Numan, S., and Dellovade, T. L. (2004). Distribution of estrogen receptor $\alpha$ and $\beta$ in the mouse central nervous system: in vivo autoradiographic and immunocytochemical analyses. J. Comp. Neurol. 473, 270-291. doi: 10.1002/cne.20128

Merchenthaler, I., Lopez, F. J., and Negro-Vilar, A. (1990). Colocalization of galanin and luteinizing hormone-releasing hormone in a subset of preoptic hypothalamic neurons: anatomical and functional correlates. Proc. Natl. Acad. Sci. U S A 87, 6326-6330. doi: 10.1073/pnas.87.16.6326

Moenter, S. M. (2010). Identified GnRH neuron electrophysiology: a decade of study. Brain Res. 1364, 10-24. doi: 10.1016/j.brainres. 2010.09.066

Moenter, S. M., Chu, Z., and Christian, C. A. (2009). Neurobiological mechanisms underlying oestradiol negative and positive feedback regulation of gonadotrophin-releasing hormone neurones. J. Neuroendocrinol. 21, 327-333. doi: $10.1111 / j .1365-2826.2009 .01826 . x$

Murai, K. K., and Pasquale, E. B. (2011). Eph receptors and ephrins in neuronastrocyte communication at synapses. Glia 59, 1567-1578. doi: 10.1002/glia. 21226

Murr, S. M., Geschwind, I. I., and Bradford, G. E. (1973). Plasma LH and FSH during different oestrous cycle conditions in mice. J. Reprod. Fertil. 32, 221-230. doi: 10.1530/jrf.0.0320221

Nakata, M., Sano, K., Musatov, S., Yamaguchi, N., Sakamoto, T., and Ogawa, S. (2016). Effects of prepubertal or adult site-specific knockdown of estrogen receptor $\beta$ in the medial preoptic area and medial amygdala on social behaviors in male mice. eNeuro 3:ENEURO.0155-15.2016. doi: 10.1523/ENEURO.015515.2016

Nelson, J. F., Felicio, L. S., Randall, P. K., Sims, C., and Finch, C. E. (1982). A longitudinal study of estrous cyclicity in aging C57BL/6J mice: I. Cycle frequency, length and vaginal cytology. Biol. Reprod. 27, 327-339. doi: 10.1095/biolreprod27.2.327

Okamura, H., Yokosuka, M., and Hayashi, S. (1994). Induction of substance P-immunoreactivity by estrogen in neurons containing estrogen receptors in the anterovental periventricular nucleus of female but not male rats. J. Neuroendocrinol. 6, 609-615. doi: 10.1111/j.1365-2826.1994. tb00626.x

Ottem, E. N., Godwin, J. G., Krishnan, S., and Petersen, S. L. (2004). Dual-phenotype GABA/glutamate neurons in adult preoptic area: sexual dimorphism and function. J. Neurosci. 24, 8097-8105. doi: 10.1523/JNEUROSCI.2267-04.2004

Overgaard, A., Tena-Sempere, M., Franceschini, I., Desroziers, E., Simonneaux, V., and Mikkelsen, J. D. (2013). Comparative analysis of kisspeptinimmunoreactivity reveals genuine differences in the hypothalamic Kiss1 systems between rats and mice. Peptides 45, 85-90. doi: 10.1016/j. peptides.2013.04.013
Paradis, E., Clavel, S., Bouillaud, F., Ricquier, D., and Richard, D. (2003). Uncoupling protein 2: a novel player in neuroprotection. Trends Mol. Med. 9, 522-525. doi: 10.1016/j.molmed.2003.10.009

Paredes, R. G. (2003). Medial preoptic area/anterior hypothalamus and sexual motivation. Scand. J. Psychol. 44, 203-212. doi: 10.1111/1467-9450. 00337

Penatti, C. A., Davis, M. C., Porter, D. M., and Henderson, L. P. (2010), Altered $\mathrm{GABA}_{\mathrm{A}}$ receptor-mediated synaptic transmission disrupts the firing of gonadotropin-releasing hormone neurons in male mice under conditions that mimic steroid abuse. J. Neurosci. 30, 6497-6506. doi: 10.1523/JNEUROSCI. 5383-09.2010

Petersen, S. L., Cheuk, C., Hartman, R. D., and Barraclough, C. A. (1989). Medial preoptic microimplants of the antiestrogen, keoxifene, affect luteinizing hormone-releasing hormone mRNA levels, median eminence luteinizing hormone-releasing hormone concentrations and luteinizing hormone release in ovariectomized, estrogen-treated rats. J. Neuroendocrinol. 1, 279-283. doi: 10.1111/j.1365-2826.1989.tb00116.x

Piet, R., Boehm, U., and Herbison, A. E. (2013). Estrous cycle plasticity in the hyperpolarization-activated current ih is mediated by circulating $17 \beta$ estradiol in preoptic area kisspeptin neurons. J. Neurosci. 33, 10828-10839. doi: 10.1523/JNEUROSCI.1021-13.2013

Porteous, R., Petersen, S. L., Yeo, S. H., Bhattarai, J. P., Ciofi, P., de Tassigny, X. D., et al. (2011). Kisspeptin neurons co-express met-enkephalin and galanin in the rostral periventricular region of the female mouse hypothalamus. J. Comp. Neurol. 519, 3456-3469. doi: 10.1002/cne.22716

Rajendren, G. (2002). Increased galanin synapses onto activated gonadotropin-releasing hormone neuronal cell bodies in normal female mice and in functional preoptic area grafts in hypogonadal mice. J. Neuroendocrinol. 14, 435-441. doi: 10.1046/j.1365-2826. 2002.00796.x

Sakurada, K., Ohshima-Sakurada, M., Palmer, T. D., and Gage, F. H. (1999). Nurr1, an orphan nuclear receptor, is a transcriptional activator of endogenous tyrosine hydroxylase in neural progenitor cells derived from the adult brain. Development 126, 4017-4026.

Sano, K., Tsuda, M. C., Musatov, S., Sakamoto, T., and Ogawa, S. (2013). Differential effects of site-specific knockdown of estrogen receptor $\alpha$ in the medial amygdala, medial pre-optic area and ventromedial nucleus of the hypothalamus on sexual and aggressive behavior of male mice. Eur. J. Neurosci. 37, 1308-1319. doi: 10.1111/ejn.12131

Shughrue, P., Scrimo, P., Lane, M., Askew, R., and Merchenthaler, I. (1997). The distribution of estrogen receptor- $\beta$ mRNA in forebrain regions of the estrogen receptor- $\alpha$ knockout mouse. Endocrinology 138, 5649-5652. doi: 10.1210/en. 138.12.5649

Silveira, M. A., Burger, L. L., DeFazio, R. A., Wagenmaker, E. R., and Moenter, S. M. (2017). GnRH neuron activity and pituitary response in estradiol-induced vs. proestrous luteinizing hormone surges in female mice. Endocrinology 158, 356-366. doi: 10.1210/en.2016-1771

Simerly, R. B. (1998). Organization and regulation of sexually dimorphic neuroendocrine pathways. Behav. Brain Res. 92, 195-203. doi: 10.1016/s01664328(97)00191-5

Simerly, R. B., Carr, A. M., Zee, M. C., and Lorang, D. (1996). Ovarian steroid regulation of estrogen and progesterone receptor messenger ribonucleic acid in the anteroventral periventricular nucleus of the rat. J. Neuroendocrinol. 8, 45-56. doi: 10.1111/j.1365-2826.1996.tb00685.x

Simerly, R. B., Chang, C., Muramatsu, M., and Swanson, L. W. (1990). Distribution of androgen and estrogen receptor mRNA-containing cells in the rat brain: an in situ hybridization study. J. Comp. Neurol. 294, 76-95. doi: 10.1002/cne. 902940107

Simerly, R. B., and Swanson, L. W. (1987). The distribution of neurotransmitterspecific cells and fibers in the anteroventral periventricular nucleus: implications for the control of gonadotropin secretion in the rat. Brain Res. 400, 11-34. doi: 10.1016/0006-8993(87)90649-4

Simerly, R. B., and Swanson, L. W. (1988). Projections of the medial preoptic nucleus: a Phaseolus vulgaris leucoagglutinin anterograde tracttracing study in the rat. J. Comp. Neurol. 270, 209-242. doi: 10.1002/cne. 902700205

Simerly, R. B., Zee, M. C., Pendleton, J. W., Lubahn, D. B., and Korach, K. S. (1997). Estrogen receptor-dependent sexual differentiation of dopaminergic 
neurons in the preoptic region of the mouse. Proc. Natl. Acad. Sci. U S A 94, 14077-14082. doi: 10.1073/pnas.94.25.14077

Skrapits, K., Borsay, B. A., Herczeg, L., Ciofi, P., Liposits, Z., and Hrabovszky, E. (2015). Neuropeptide co-expression in hypothalamic kisspeptin neurons of laboratory animals and the human. Front. Neurosci. 9:29. doi: 10.3389/fnins. 2015.00029

Smith, J. T., Clifton, D. K., and Steiner, R. A. (2006a). Regulation of the neuroendocrine reproductive axis by kisspeptin-GPR54 signaling. Reproduction 131, 623-630. doi: 10.1530/rep.1.00368

Smith, J. T., Popa, S. M., Clifton, D. K., Hoffman, G. E., and Steiner, R. A. (2006b). Kiss1 neurons in the forebrain as central processors for generating the preovulatory luteinizing hormone surge. J. Neurosci. 26, 6687-6694. doi: 10.1523/JNEUROSCI.1618-06.2006

Smith, J. T., Cunningham, M. J., Rissman, E. F., Clifton, D. K., and Steiner, R. A. (2005). Regulation of Kiss1 gene expression in the brain of the female mouse. Endocrinology 146, 3686-3692. doi: 10.1210/en. 2005-0488

Smith, M. J., and Wise, P. M. (2001). Neurotensin gene expression increases during proestrus in the rostral medial preoptic nucleus: potential for direct communication with gonadotropin-releasing hormone neurons. Endocrinology 142, 3006-3013. doi: 10.1210/en.142.7.3006

Szklarczyk, D., Franceschini, A., Wyder, S., Forslund, K., Heller, D., HuertaCepas, J., et al. (2015). STRING v10: protein-protein interaction networks, integrated over the tree of life. Nucleic Acids Res. 43, D447-D452. doi: 10.1093/nar/gku1003

Taylor-Burds, C., Cheng, P., and Wray, S. (2015). Chloride accumulators $\mathrm{NKCC} 1$ and $\mathrm{AE} 2$ in mouse GnRH neurons: implications for GABAA mediated excitation. PLoS One 10:e0131076. doi: 10.1371/journal.pone.0131076

Todman, M. G., Han, S. K., and Herbison, A. E. (2005). Profiling neurotransmitter receptor expression in mouse gonadotropin-releasing hormone neurons using green fluorescent protein-promoter transgenics and microarrays. Neuroscience 132, 703-712. doi: 10.1016/j.neuroscience. 2005.01.035

Treen, A. K., Luo, V., Chalmers, J. A., Dalvi, P. S., Tran, D., Ye, W., et al. (2016). Divergent regulation of ER and kiss genes by $17 \beta$-estradiol in hypothalamic ARC versus AVPV models. Mol. Endocrinol. 30, 217-233. doi: 10.1210/me. 2015-1189

Tsuneoka, Y., Maruyama, T., Yoshida, S., Nishimori, K., Kato, T., Numan, M., et al. (2013). Functional, anatomical and neurochemical differentiation of medial preoptic area subregions in relation to maternal behavior in the mouse. J. Comp. Neurol. 521, 1633-1663. doi: 10.1002/cne. 23251

Vastagh, C., Rodolosse, A., Solymosi, N., and Liposits, Z. (2016). Altered expression of genes encoding neurotransmitter receptors in GnRH neurons of proestrous mice. Front. Cell. Neurosci. 10:230. doi: 10.3389/fncel. 2016.00230
Vastagh, C., Rodolosse, A., Solymosi, N., Farkas, I., Auer, H., Sárvári, M., et al. (2015). Differential gene expression in gonadotropin-releasing hormone neurons of male and metestrous female mice. Neuroendocrinology 102, 44-59. doi: $10.1159 / 000430818$

Wang, L., DeFazio, R. A., and Moenter, S. M. (2016). Excitability and burst generation of AVPV kisspeptin neurons are regulated by the estrous cycle via multiple conductances modulated by estradiol action. eNeuro 3:ENEURO.0094-16.2016. doi: 10.1523/ENEURO.0094-16.2016

Wintermantel, T. M., Campbell, R. E., Porteous, R., Bock, D., Gröne, H. J., Todman, M. G., et al. (2006). Definition of estrogen receptor pathway critical for estrogen positive feedback to gonadotropin-releasing hormone neurons and fertility. Neuron 52, 271-280. doi: 10.1016/j.neuron.2006.07.023

Wu, Z., Autry, A. E., Bergan, J. F., Watabe-Uchida, M., and Dulac, C. G. (2014). Galanin neurons in the medial preoptic area govern parental behaviour. Nature 509, 325-330. doi: 10.1038/nature13307

Yeo, S. H., Kyle, V., Morris, P. G., Jackman, S., Sinnett-Smith, L. C., Schacker, M., et al. (2016). Visualisation of kiss1 neurone distribution using a kiss1-CRE transgenic mouse. J. Neuroendocrinol. 28:11. doi: 10.1111/jne. 12435

Yip, S. H., Boehm, U., Herbison, A. E., and Campbell, R. E. (2015). Conditional viral tract tracing delineates the projections of the distinct kisspeptin neuron populations to gonadotropin-releasing hormone $(\mathrm{GnRH})$ neurons in the mouse. Endocrinology 156, 2582-2594. doi: 10.1210/en.2015-1131

Zhang, C., Bosch, M. A., Qiu, J., Rønnekleiv, O. K., and Kelly, M. J. (2015). $17 \beta$-Estradiol increases persistent $\mathrm{Na}^{+}$current and excitability of AVPV/PeN Kiss1 neurons in female mice. Mol. Endocrinol. 29, 518-527. doi: 10.1210/me. 2014-1392

Zhang, C., Tonsfeldt, K. J., Qiu, J., Bosch, M. A., Kobayashi, K., Steiner, R. A., et al. (2013). Molecular mechanisms that drive estradiol-dependent burst firing of Kiss1 neurons in the rostral periventricular preoptic area. Am. J. Physiol. Endocrinol. Metab. 305, E1384-E1397. doi: 10.1152/ajpendo. 00406.2013

Zuloaga, D. G., Zuloaga, K. L., Hinds, L. R., Carbone, D. L., and Handa, R. J. (2014). Estrogen receptor $\beta$ expression in the mouse forebrain: age and sex differences. J. Comp. Neurol. 522, 358-371. doi: 10.1002/cne.23400

Conflict of Interest Statement: The authors declare that the research was conducted in the absence of any commercial or financial relationships that could be construed as a potential conflict of interest.

Copyright $\odot 2017$ Vastagh and Liposits. This is an open-access article distributed under the terms of the Creative Commons Attribution License (CC BY). The use, distribution or reproduction in other forums is permitted, provided the original author(s) or licensor are credited and that the original publication in this journal is cited, in accordance with accepted academic practice. No use, distribution or reproduction is permitted which does not comply with these terms. 